Article

\title{
Hydration and Mechanical Properties of Calcium Sulphoaluminate Cement Containing Calcium Carbonate and Gypsum under $\mathrm{NaCl}$ Solutions
}

\author{
Jianzheng Wang ${ }^{1}$, Shilin Song ${ }^{1}$, Yu Zhang ${ }^{1,2,3, *}$, Tao Xing ${ }^{1}$, Ying Ma ${ }^{1}$ and Haiyan Qian ${ }^{1, *}$ \\ 1 College of Materials Science and Engineering, Nanjing Tech University, Nanjing 211816, China; \\ 201961203182@njtech.edu.cn (J.W.); 202061103080@njtech.edu.cn (S.S.); 201861103080@njtech.edu.cn (T.X.); \\ maying@njtech.edu.cn (Y.M.) \\ 2 State Key Laboratory of Materials-Oriented Chemical Engineering, Nanjing Tech University, \\ Nanjing 211816, China \\ 3 Quechen Silicon Chemical Co., Ltd., Wuxi 214196, China \\ * Correspondence: zhangyuzeus@njtech.edu.cn (Y.Z.); qianhaiy@163.com (H.Q.)
}

Citation: Wang, J.; Song, S.; Zhang, Y.; Xing, T.; Ma, Y.; Qian, H. Hydration and Mechanical Properties of Calcium Sulphoaluminate Cement Containing Calcium Carbonate and Gypsum under $\mathrm{NaCl}$ Solutions. Materials 2022, 15, 816. https:// doi.org/10.3390/ma15030816

Academic Editor: Didier Snoeck

Received: 30 November 2021

Accepted: 17 January 2022

Published: 21 January 2022

Publisher's Note: MDPI stays neutral with regard to jurisdictional claims in published maps and institutional affiliations.

Copyright: (C) 2022 by the authors. Licensee MDPI, Basel, Switzerland. This article is an open access article distributed under the terms and conditions of the Creative Commons Attribution (CC BY) license (https:// creativecommons.org/licenses/by/ $4.0 /)$.

\begin{abstract}
Hydration characteristics and mechanical properties of calcium sulphoaluminate (CSA) cement with different contents of $\mathrm{CaCO}_{3}$ and gypsum under $\mathrm{NaCl}$ solutions were studied, using the testing methods of isothermal calorimetry, X-ray diffraction (XRD), mercury intrusion porosimetry (MIP), linear shrinkage, and compressive strength. Results show that $\mathrm{CaCO}_{3}$ can promote hydration and reduce the hydration heat of CSA cement. The reaction between gypsum and $\mathrm{C}_{4} \mathrm{~A}_{3} \overline{\mathrm{S}}$ releases a large quantity of heat in the initial hydration period; however, over 3 days of accumulation, the level of hydration heat is reduced. Under $\mathrm{NaCl}$ solutions, the aluminate phase has difficulty reacting with $\mathrm{CaCO}_{3}$ to form carbonate phase but combines with chloride ions to form Friedel's salt. On the contrary, gypsum reduces aluminate phase, and the content of Friedel's salt is also reduced. Furthermore, $\mathrm{CaCO}_{3}$ and gypsum both increase the total porosity of the CSA cement paste under $\mathrm{NaCl}$ solutions during the early curing phase, and over the long-term, pore structure is also optimized. $\mathrm{CaCO}_{3}$ and gypsum reduce the linear shrinkage of CSA cement paste under $\mathrm{NaCl}$ solutions. Overall, the compressive strength of CSA cement is reduced with the addition of $\mathrm{CaCO}_{3}$, and the trend will be sharper with the increase in $\mathrm{CaCO}_{3}$. However, when it comes to gypsum, the compressive strength is almost the same during early curing, but in the long-term, compressive strength improves. Essentially, the compressive strength of CSA cement mortar with $\mathrm{CaCO}_{3}$ and gypsum will improve under $\mathrm{NaCl}$ solutions.
\end{abstract}

Keywords: calcium sulphoaluminate cement; calcium carbonate; gypsum; hydration; compressive strength; $\mathrm{NaCl}$ solutions

\section{Introduction}

With the exploration of marine resources and the development of the marine industry, requirement for the construction of offshore infrastructure is increasing. During the last two centuries, ordinary Portland cement (OPC) was widely used in marine engineering construction. However, the total amount of energy consumption and carbon dioxide emission during the production of OPC was huge. Moreover, the main hydration products of OPC are $\mathrm{Ca}(\mathrm{OH})_{2}$ and C-S-H gel, which easily eroded under marine conditions $[1,2]$. Herein, demand for new low-carbon cementitious materials with high corrosion resistance is increasing.

Calcium sulphoaluminate (CSA) cement is a kind of cementitious material with low carbon emissions and low energy consumption, as well as good performance in resisting seawater erosion. It has been drawing great interest among industry experts and scientists since the 1970s [3-7]. CSA cement was independently researched and invented by China's 
Academy of Building Materials Science in the 1970s and has been investigated and used for over 40 years [8,9]. However, CSA cement was mainly used as a special cementitious material in marine engineering for construction crack compensation or frigid construction, owning to its shortcomings of rapid hardening, low long-term strength, and fewer applications in field construction $[10,11]$.

As is well known, concrete will inevitably erode or be destroyed under marine conditions or high chloride content environments as chloride ions permeate, while the erosion level of concrete is related to factors of permeation time, chloride ion concentration, temperature, and humidity, etc. [12-14]. Several studies have shown that AFm phase can combine chloride ions through chemical reactions, while the C-S-H gel combines chloride ions through physical bonding. Herein, the presence of C-S-H gel could delay the infiltration process and reduce the chloride concentration in concrete pore solutions, which is contributes greatly to improving the structural strength of concrete $[15,16]$.

The main minerals in CSA cement are ye'elimite $\left(4 \mathrm{CaO} \cdot 3 \mathrm{Al}_{2} \mathrm{O}_{3} \cdot \mathrm{SO}_{3}, \mathrm{C}_{4} \mathrm{~A}_{3} \overline{\mathrm{S}}(\mathrm{Cement}\right.$ nomenclature will be used, i.e., $\left.\mathrm{SO}_{3}=\overline{\mathrm{S}}, \mathrm{SiO}_{2}=\mathrm{S}, \mathrm{CaO}=\mathrm{C}, \mathrm{Al}_{2} \mathrm{O}_{3}=\mathrm{A}, \mathrm{CO}_{2}=\overline{\mathrm{C}}, \mathrm{H}_{2} \mathrm{O}=\mathrm{H}\right)$ ), dicalcium silicate $\left(2 \mathrm{CaO} \cdot \mathrm{SiO}_{2}, \mathrm{C}_{2} \mathrm{~S}\right)$, anhydrite $\left(\mathrm{CaSO}_{4}\right)$, and iron phase. The reaction rate of $\mathrm{C}_{4} \mathrm{~A}_{3} \overline{\mathrm{S}}$ is very fast, providing high early-stage strength for CSA cement. The hydration of $\mathrm{C}_{2} \mathrm{~S}$ is very slow, which could improve the later life strength of CSA cement. $\mathrm{CaSO}_{4}$ is mainly added to control the reaction rate of CSA cement and to react with $\mathrm{C}_{4} \mathrm{~A}_{3} \overline{\mathrm{S}}$ to form ettringite. $\mathrm{CaCO}_{3}$ is mainly added to cement as a filler to reduce costs [17]. The chemical reactions of the main minerals in CSA cement are shown:

$$
\begin{gathered}
\mathrm{C}_{4} \mathrm{~A}_{3} \overline{\mathrm{S}}+18 \mathrm{H}=\mathrm{C}_{4} \mathrm{~A} \overline{\mathrm{S}} \mathrm{H}_{12}(\mathrm{AFm})+2 \mathrm{AH}_{3}, \\
\mathrm{C}_{4} \mathrm{~A}_{3} \overline{\mathrm{S}}+2 \mathrm{C} \overline{\mathrm{S}}+38 \mathrm{H}=\mathrm{C}_{6} \mathrm{AS}_{3} \mathrm{H}_{32}(\mathrm{AFt})+2 \mathrm{AH}_{3}, \\
2 \mathrm{C}_{2} \mathrm{~S}+4 \mathrm{H}=\mathrm{C}-\mathrm{S}-\mathrm{H}+\mathrm{CH},
\end{gathered}
$$

(Notation with: $\mathrm{C}=\mathrm{CaO}, \mathrm{A}=\mathrm{Al}_{2} \mathrm{O}_{3}, \overline{\mathrm{S}}=\mathrm{SO}_{3}, \mathrm{~S}=\mathrm{SiO}_{2}, \mathrm{H}=\mathrm{H}_{2} \mathrm{O}$ ).

In recent years, several kinds of $\mathrm{CaCO}_{3}$ were investigated as possible cement fillers in various studies, such as limestone powder [17-19], dolomite powder [20], and coral sand powder [21,22]. Results show that $\mathrm{CaCO}_{3}$ can promote the early hydration of cement and can react with $\mathrm{C}_{4} \mathrm{~A}_{3} \overline{\mathrm{S}}$ to form hemicarbonate $\left(4 \mathrm{CaO} \cdot \mathrm{Al}_{2} \mathrm{O}_{3} \cdot 0.5 \mathrm{CO}_{2} \cdot 12 \mathrm{H}_{2} \mathrm{O}, \mathrm{Hc}\right)$ and monocarbonate $\left(4 \mathrm{CaO} \cdot \mathrm{Al}_{2} \mathrm{O}_{3} \cdot \mathrm{CO}_{2} \cdot 11 \mathrm{H}_{2} \mathrm{O}, \mathrm{Mc}\right)$, which can stabilize ettringite and refine the pore structure of cement $[23,24]$. Gypsum can adjust the setting time of cement, control the hydration rate, affect the composition of hydration products, and adjust the strength and expansion capacity of cement [25]. Different types of gypsum play different roles [26,27].

It is hard to ignore the fact that the freshwater and other raw materials required for offshore construction are difficult to attain, because the transportation of freshwater and raw materials is expensive. It follows, that increasing the use of seawater and local materials will shorten construction time and reduce the transportation cost of materials [28-30]. Once concrete has been exposed to a chloride ion rich environment over the long term, it will inevitably be destroyed by the infiltrating chloride ion [31,32]. $\mathrm{NaCl}$ can accelerate cement hydration in the early stages of hydration. In $\mathrm{NaCl}$ solutions, $\mathrm{NaCl}$ can accelerate the dissolution of gypsum to form ettringite and increase the heat of hydration [33-35]. Meanwhile, $\mathrm{NaCl}$ can significantly increase the compressive strength of cement [36]. In this work, the hydration process, compressive strength development and linear expansion rate of CSA cement will be detailed, by illustrating the testing methods of isothermal calorimetry, $\mathrm{X}$-ray diffraction, and pore structure development in the presence of different contents of $\mathrm{CaCO}_{3}$ and gypsum under fresh water and $\mathrm{NaCl}$ solutions.

\section{Materials and Methods}

\subsection{Raw Materials}

The CSA cement used in this study was a variety of low-alkali CSA cement, which was produced by the Tangshan Liujiu Cement Co., Ltd., Tangshan, China. The $\mathrm{CaCO}_{3}$, 
$\mathrm{CaSO}_{4} \cdot 2 \mathrm{H}_{2} \mathrm{O}$, and $\mathrm{NaCl}$ used were all analytical grade (AR) reagents (99.5\% content). The chemical composition of CSA cement is shown in Table 1. Figure 1 presents the XRD pattern of CSA cement and the XRD pattern of $\mathrm{CaCO}_{3}$ and gypsum are shown in Figure 2. As tested, the main mineral phases of CSA cement are ye'elimite $\left(\mathrm{C}_{4} \mathrm{~A}_{3} \overline{\mathrm{S}}\right)$, dicalcium silicate $\left(\mathrm{C}_{2} \mathrm{~S}\right)$, anhydrite $\left(\mathrm{CaSO}_{4}\right)$, mayenite $\left(12 \mathrm{CaO} \cdot 7 \mathrm{Al}_{2} \mathrm{O}_{3}, \mathrm{C}_{12} \mathrm{~A}_{7}\right)$, and calcite $\left(\mathrm{CaCO}_{3}\right)$. The mineral phase quantitative analysis of CSA cement is shown in Table 2 using the software $X^{\prime}$ Pert HighScore Plus version 3.0e.

Table 1. Chemical composition of CSA cement.

\begin{tabular}{cc} 
Oxide & CSA Cement \\
\hline Calcium oxide, $\mathrm{CaO}$ & 42.97 \\
Silicon dioxide, $\mathrm{SiO}_{2}$ & 13.85 \\
Aluminum oxide, $\mathrm{Al}_{2} \mathrm{O}_{3}$ & 22.14 \\
Sulfur trioxide, $\mathrm{SO}_{3}$ & 11.86 \\
Ferric oxide, $\mathrm{Fe}_{2} \mathrm{O}_{3}$ & 1.33 \\
Magnesium oxide, $\mathrm{MgO}$ & 2.86 \\
Potassium oxide, $\mathrm{K}_{2} \mathrm{O}$ & 0.31 \\
Sodium oxide, $\mathrm{Na}_{2} \mathrm{O}$ & 0.09 \\
Titanium oxide, $\mathrm{TiO}_{2}$ & 0.97 \\
Manganese Oxide, $\mathrm{MnO}$ & 0.034 \\
Phosphorus Pentoxide, $\mathrm{P}_{2} \mathrm{O}_{5}$ & 0.16 \\
Loss on ignition, $\mathrm{LOI}$ & 2.76
\end{tabular}

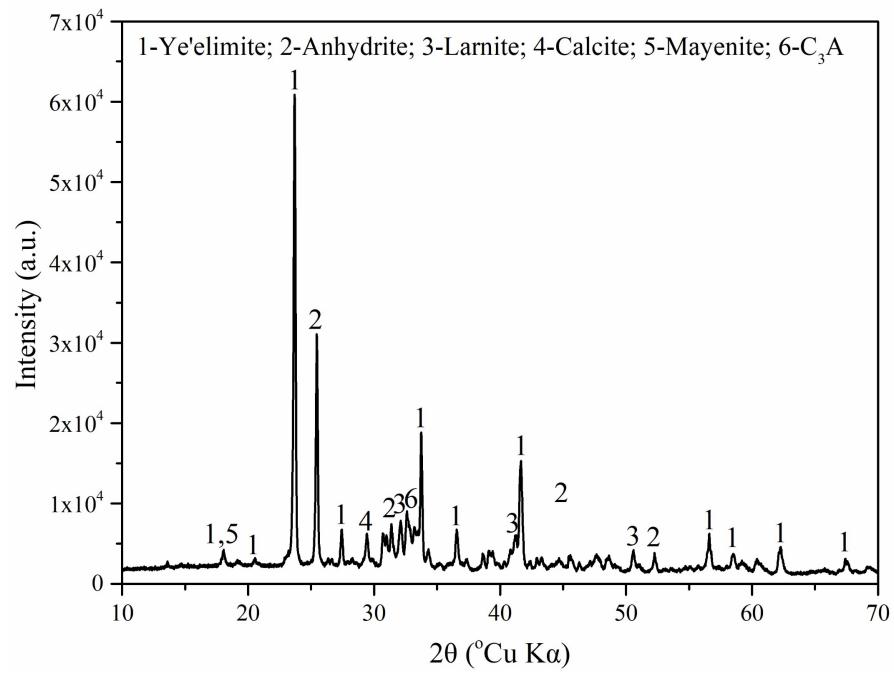

Figure 1. XRD pattern of CSA cement.
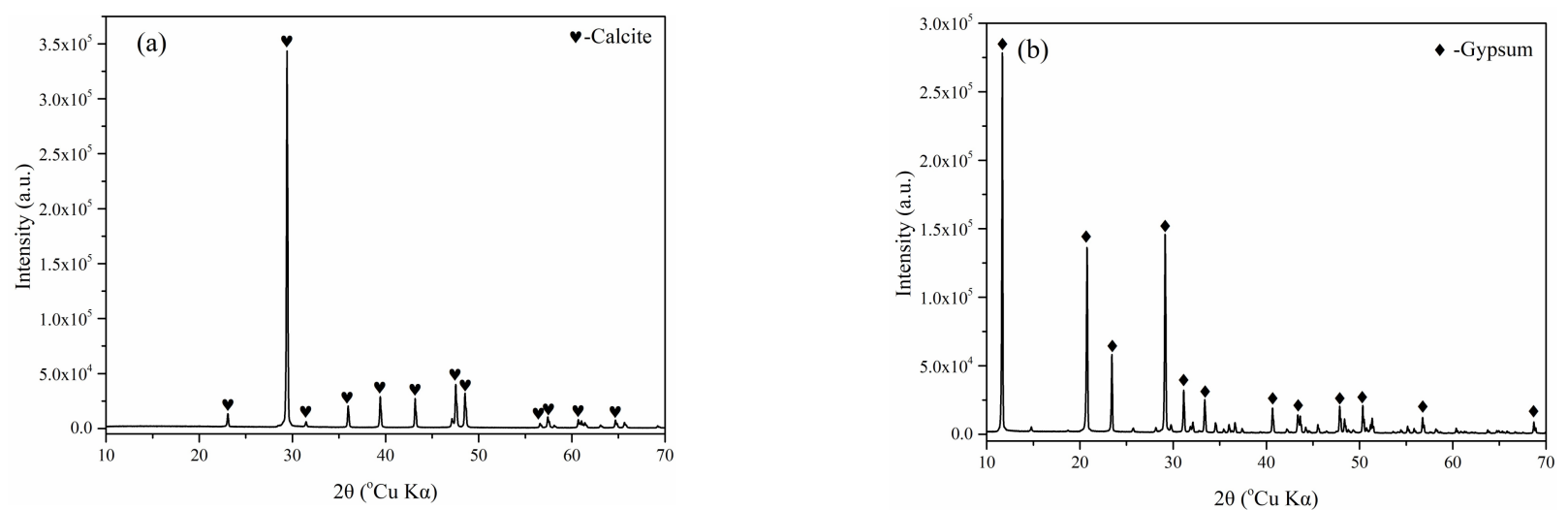

Figure 2. $\mathrm{XRD}$ pattern of $\mathrm{CaCO}_{3}(\mathbf{a})$ and gypsum (b). 
Table 2. Mineral composition of CSA cement.

\begin{tabular}{cc}
\hline Mineral & Content/\% \\
\hline $\mathrm{C}_{4} \mathrm{~A}_{3} \overline{\mathrm{S}}$ & 51.53 \\
$\mathrm{C}_{2} \mathrm{~S}$ & 21.25 \\
$\mathrm{C}_{3} \mathrm{~A}$ & 1.71 \\
$\mathrm{CaSO}_{4}$ & 11.52 \\
$\mathrm{CaCO}_{3}$ & 9.81 \\
$\mathrm{C}_{2} \mathrm{~A}_{7}$ & 1.28 \\
\hline
\end{tabular}

\subsection{Sample Preparation}

Powder compositions of samples were accurately weighed and well-mixed separately for over $10 \mathrm{~h}$ in mixers before they were hydrated with water/solutions. Detailed proportions of the samples are shown in Table 3. Figure 3 shows raw materials being mixed in the mixing machine and the mixtures being stirred with water or solutions in blenders, respectively.

Table 3. Mixture proportion of all samples (wt\%).

\begin{tabular}{|c|c|c|c|c|c|c|}
\hline Samples & w/c & Cement & $\mathrm{CaCO}_{3}$ & Gypsum & $\begin{array}{l}\text { Water for } \\
\text { Mixing }\end{array}$ & $\begin{array}{l}\text { Water for } \\
\text { Curing }\end{array}$ \\
\hline $\mathrm{C}$ & 0.5 & 100 & 0 & 0 & Deionized water & Deionized water \\
\hline CC5 & 0.5 & 95 & 5 & 0 & Deionized water & Deionized water \\
\hline CC10 & 0.5 & 90 & 10 & 0 & Deionized water & Deionized water \\
\hline CC15 & 0.5 & 85 & 15 & 0 & Deionized water & Deionized water \\
\hline CS5 & 0.5 & 95 & 0 & 5 & Deionized water & Deionized water \\
\hline CS10 & 0.5 & 90 & 0 & 10 & Deionized water & Deionized water \\
\hline$C-1$ & 0.5 & 100 & 0 & 0 & Deionized water & $\begin{array}{c}3.5 \% \mathrm{NaCl} \\
\text { solution }\end{array}$ \\
\hline CC5-1 & 0.5 & 95 & 5 & 0 & Deionized water & $\begin{array}{l}3.5 \% \mathrm{NaCl} \\
\text { solution }\end{array}$ \\
\hline CC10-1 & 0.5 & 90 & 10 & 0 & Deionized water & $\begin{array}{l}3.5 \% \mathrm{NaCl} \\
\text { solution }\end{array}$ \\
\hline CC15-1 & 0.5 & 85 & 15 & 0 & Deionized water & $\begin{array}{l}3.5 \% \mathrm{NaCl} \\
\text { solution }\end{array}$ \\
\hline CS5-1 & 0.5 & 95 & 0 & 5 & Deionized water & $\begin{array}{l}3.5 \% \mathrm{NaCl} \\
\text { solution }\end{array}$ \\
\hline CS10-1 & 0.5 & 90 & 0 & 10 & Deionized water & $\begin{array}{l}3.5 \% \mathrm{NaCl} \\
\text { solution }\end{array}$ \\
\hline$C-2$ & 0.5 & 100 & 0 & 0 & $\begin{array}{l}3.5 \% \mathrm{NaCl} \\
\text { solution }\end{array}$ & $\begin{array}{l}3.5 \% \mathrm{NaCl} \\
\text { solution }\end{array}$ \\
\hline CC5-2 & 0.5 & 95 & 5 & 0 & $\begin{array}{l}3.5 \% \mathrm{NaCl} \\
\text { solution }\end{array}$ & $\begin{array}{l}3.5 \% \mathrm{NaCl} \\
\text { solution }\end{array}$ \\
\hline CC10-2 & 0.5 & 90 & 10 & 0 & $\begin{array}{l}3.5 \% \mathrm{NaCl} \\
\text { solution }\end{array}$ & $\begin{array}{l}3.5 \% \mathrm{NaCl} \\
\text { solution }\end{array}$ \\
\hline CC15-2 & 0.5 & 85 & 15 & 0 & $\begin{array}{l}3.5 \% \mathrm{NaCl} \\
\text { solution }\end{array}$ & $\begin{array}{l}3.5 \% \mathrm{NaCl} \\
\text { solution }\end{array}$ \\
\hline CS5-2 & 0.5 & 95 & 0 & 5 & $\begin{array}{l}3.5 \% \mathrm{NaCl} \\
\text { solution }\end{array}$ & $\begin{array}{l}3.5 \% \mathrm{NaCl} \\
\text { solution }\end{array}$ \\
\hline CS10-2 & 0.5 & 90 & 0 & 10 & $\begin{array}{l}3.5 \% \mathrm{NaCl} \\
\text { solution }\end{array}$ & $\begin{array}{l}3.5 \% \mathrm{NaCl} \\
\text { solution }\end{array}$ \\
\hline
\end{tabular}

Afterwards, cement pastes of the mixtures were prepared by an overhead stirrer separately with a water-to-cement ratio $(\mathrm{w} / \mathrm{c})$ of 0.5 under 600 revolutions per minute. The pastes were stored in sealed vessels at $20^{\circ} \mathrm{C}$. At each curing time, the hydrated pastes were cut into small pieces and soaked in ethanol for $24 \mathrm{~h}$, then vacuum oven dried at $40{ }^{\circ} \mathrm{C}$. Small pieces of the dried samples were used for the test of Mercury intrusion porosimetry (MIP), while the ground fine samples were prepared for the characterization of X-ray diffractometry (XRD). 
The paste samples for shrinkage tests were cast into molds with a size of $20 \mathrm{~mm} \times 20 \mathrm{~mm} \times 80 \mathrm{~mm}$ at a water/solution to binder ratio (w/b) of 0.35 . Mortars of the samples were cast using standard mortars with a proportion of cement:sand:water (solution) $=1: 3: 0.5$ and a prismatic size of $40 \mathrm{~mm} \times 40 \mathrm{~mm} \times 160 \mathrm{~mm}$. Specimens were cured in molds at $20 \pm 1{ }^{\circ} \mathrm{C}$ and $95 \%$ relative humidity $(\mathrm{RH})$ for $24 \mathrm{~h}$. Then, they were demolded and cured in water or a solutions bath until the characterization was performed.
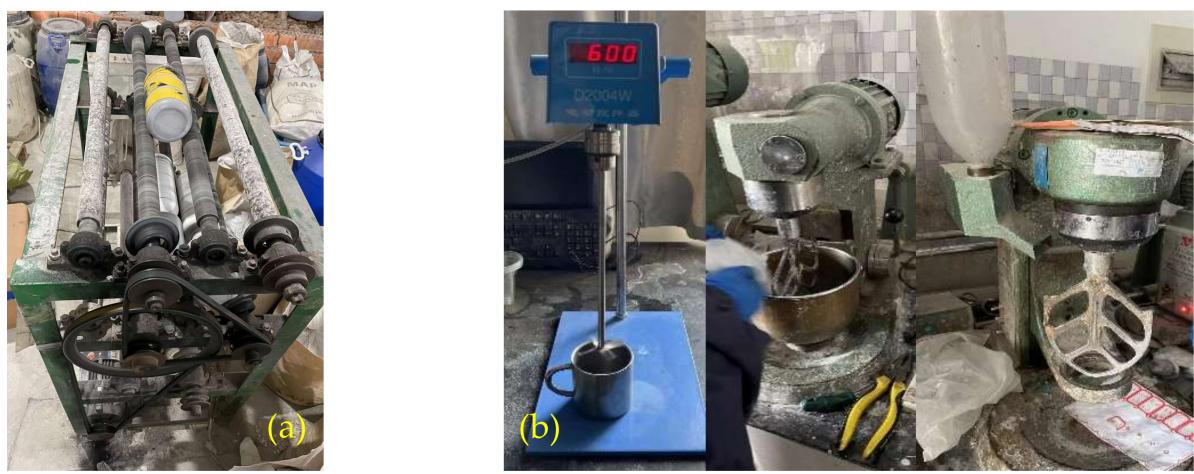

Figure 3. Mixing machine (a) and blenders (b) making the mixtures in the laboratory.

\subsection{Testing}

\subsubsection{Isothermal Calorimetry}

An 8-channel isothermal calorimeter (TAM Air; Thermometric AB, Stockholms lan, Sweden) was used to record the hydration (exothermic performance) of each sample. A total of $4 \mathrm{~g}$ of binder and $2 \mathrm{~g}$ of deionized water were mixed in standard plastic bottles. Next, bottles were immediately put in the isothermal calorimeter and the heat flow curve of the samples were recorded at a constant temperature of $20^{\circ} \mathrm{C}$ for $72 \mathrm{~h}$.

\subsubsection{X-ray Diffraction}

Rigaku's MiniFlex 600 X-ray powder diffractometer (Rigaku Corporation, Tokyo, Japan) with $\mathrm{Cu} \mathrm{K} \alpha$ radiation was used to collect the XRD data of raw materials and hydrated dry samples. Meanwhile, software HighScore Plus was used to quantitate the mineral phase compositions of the samples. The scanning was performed over an accelerating voltage of $40 \mathrm{~V}$ and a current of $15 \mathrm{~mA}$, with a $2 \theta$ range of $5-65^{\circ}$ and a $2 \theta$ increment of $0.02^{\circ}$ / step.

\subsubsection{Pore Structure Test}

MIP was used to evaluate the pore size distribution of the paste samples. The testing pore size range was $0.007-100 \mu \mathrm{m}$ with the testing pressure ranging from $1.5-350 \mathrm{kPa}$ to $140-420 \mathrm{kPa}$. The pore diameters and cumulative pore volumes could be obtained by the MIP curves.

\subsubsection{Linear Shrinkage Test}

According to JC/T 603-2004, linear shrinkage was measured by testing the length change of prismatic specimens. The specimens were demolded to place in water or a solution bath curing at $20 \pm 1{ }^{\circ} \mathrm{C}$ during the full testing period. Six specimens were prepared for each sample.

\subsubsection{Compressive Strength Test}

Compressive strength of the mortar sample was measured with a universal mechanical testing machine when there were 6 specimens to be tested for each mix and the mean value was reported according to EN-196-1-2005. 


\section{Results}

\subsection{Heat Evolution}

The heat flow and total cumulated heat curves of CSA cement and the mixed samples with $\mathrm{CaCO}_{3}$ or gypsum at a w/c of 0.5 over $72 \mathrm{~h}$ are shown in Figures 4 and 5 . It is clear that the hydration of CSA cement mixed with $\mathrm{CaCO}_{3}$ or gypsum can be divided into five stages [37]: (1) pre-induction period; (2) induction period; (3) acceleration period; (4) retarding period; and (5) stable period.
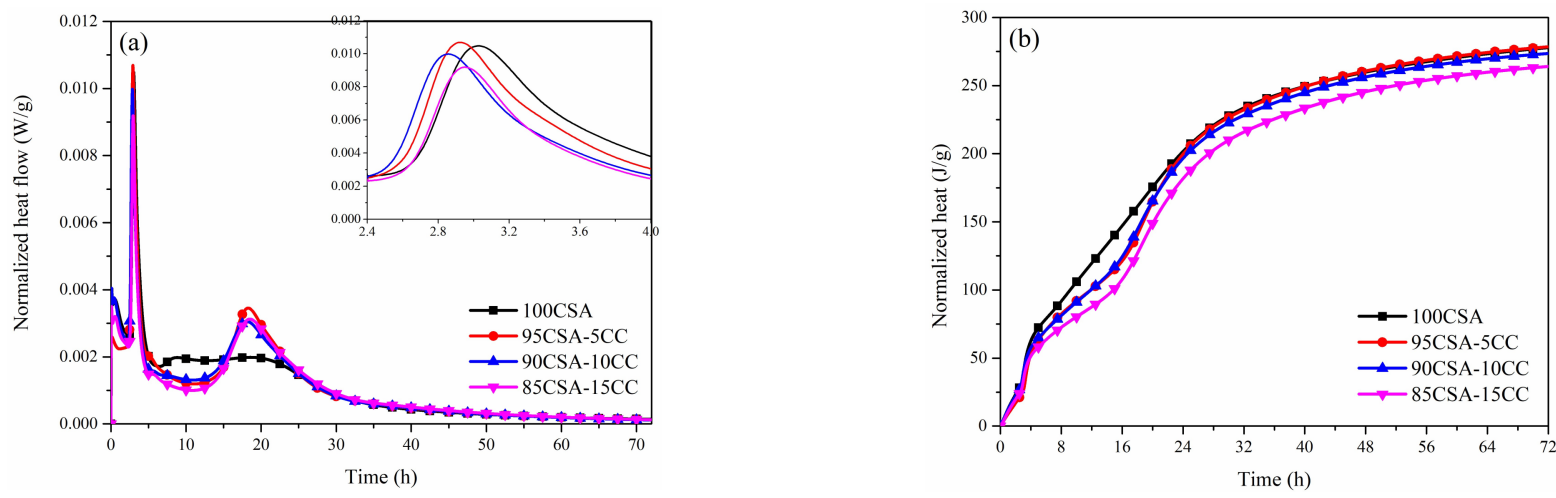

Figure 4. Heat flow curves (a) and cumulative heat curves (b) of CSA cement mixed with $\mathrm{CaCO}_{3}$.
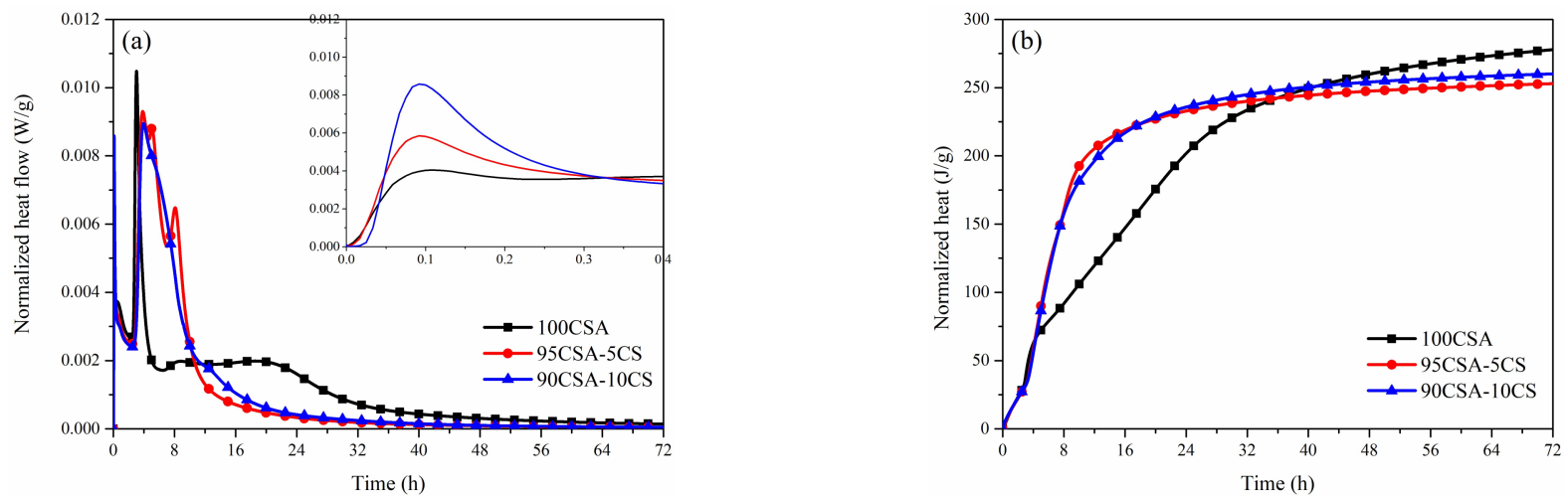

Figure 5. Heat flow curves (a) and cumulative heat curves (b) of CSA cement mixed with gypsum.

As shown in Figure 4, there are three exothermic peaks on the hydration heat release curve of CSA cement. The first exothermic peak is related to the dissolution heat release of CSA cement particles [38]. The second exothermic peak refers to the first main exothermic peak and is attributed to the hydration of $\mathrm{C}_{4} \mathrm{~A}_{3} \overline{\mathrm{S}}$ and the formation of $\mathrm{AFt}$ and aluminate hydroxide $\left(\mathrm{AH}_{3}\right)$. The third exothermic peak at around $20 \mathrm{~h}$ attributes the hydration of the remaining $\mathrm{C}_{4} \mathrm{~A}_{3} \overline{\mathrm{S}}$, leading to the formation of monosulphate when all the anhydrite is depleted [39].

$\mathrm{CaCO}_{3}$ enhances the third exothermic peak, which means the presence of $\mathrm{CaCO}_{3}$ can change the hydration process and effect the hydration product composition of CSA. It is possible that $\mathrm{CaCO}_{3}$ provides nucleation sites for hydration, which can promote the further formation of $\mathrm{AFt}$ [40]. It is worth noting that Hc or Mc phase can be formed in the presence of $\mathrm{CaCO}_{3}$, which brings the possibility of forming a sharper peak for CSA cement with $\mathrm{CaCO}_{3}$. Meanwhile, a small amount of $\mathrm{CaCO}_{3}$ can increase the total accumulated heat of CSA cement, while a large quantity of $\mathrm{CaCO}_{3}$ will show the opposite trend.

In order to compare the hydration procedure of CSA with and without gypsum, CSA with $5 \mathrm{wt} \%$ and $10 \mathrm{wt} \%$ gypsum was measured (Figure 5). The hydration of CSA was significantly advanced by the presence of gypsum, and the trend is more obvious with the increase in gypsum. The acceleration of the early hydration of CSA corresponded to 
copious amounts of $\mathrm{SO}_{4}{ }^{2-}$ promoting the rapid formation of $\mathrm{AFt}$ in the very early hydration period [25]. It is assumed that the dissolution exotherm is increased and the reaction of $\mathrm{C}_{4} \mathrm{~A}_{3} \overline{\mathrm{S}}$ is accelerated in CSA cement containing gypsum. Meanwhile, the third exothermic peak of CSA cement with $10 \mathrm{wt} \%$ gypsum disappeared, which means that AFm phase is hard to form in the early hydration period when $\mathrm{SO}_{4}{ }^{2-}$ is sufficient. As a result, the heat release of CSA cement with extra gypsum is higher than that of CSA in $24 \mathrm{~h}$, while the total accumulated hydration heat of CSA cement is reduced in the presence of gypsum within $72 \mathrm{~h}$.

\subsection{X-ray Diffraction Analyses and Phasequantitative Analyze by XRD-Rietveld Method}

Powder samples of CSA cement were investigated with XRD to identify crystalline phases at different curing stages both in water and $\mathrm{NaCl}$ solutions (Figure 6). The diffraction peaks of ettringite, $\mathrm{C}_{4} \mathrm{~A}_{3} \overline{\mathrm{S}}$, anhydrite and $\mathrm{CaCO}_{3}$ were observed at different stages. Ettringite and aluminum hydroxide $\left(\mathrm{Al}_{2} \mathrm{O}_{3} \cdot 3 \mathrm{H}_{2} \mathrm{O}, \mathrm{AH}_{3}\right)$ are the main hydration products of CSA cement, while $\mathrm{AH}_{3}$ is mainly gelatinous, and its diffraction peak is not obvious on the XRD pattern. Calcium hydroxide $\left(\mathrm{Ca}(\mathrm{OH})_{2}, \mathrm{CH}\right)$ does not appear due to its reaction with $\mathrm{AH}_{3}$ and anhydrite to form ettringite so it is consumed in the early curing phase [41], as shown in Equation (4). The diffraction peak of strätlingite is obvious in sample C after curing for 90 days. It should be noted that a small diffraction peak of Friedel's salt appears around $11.2^{\circ}$ within 3 days in C-2, which indicates that chloride ions had been mixed into the paste and chemically combined with AFm phase [42].
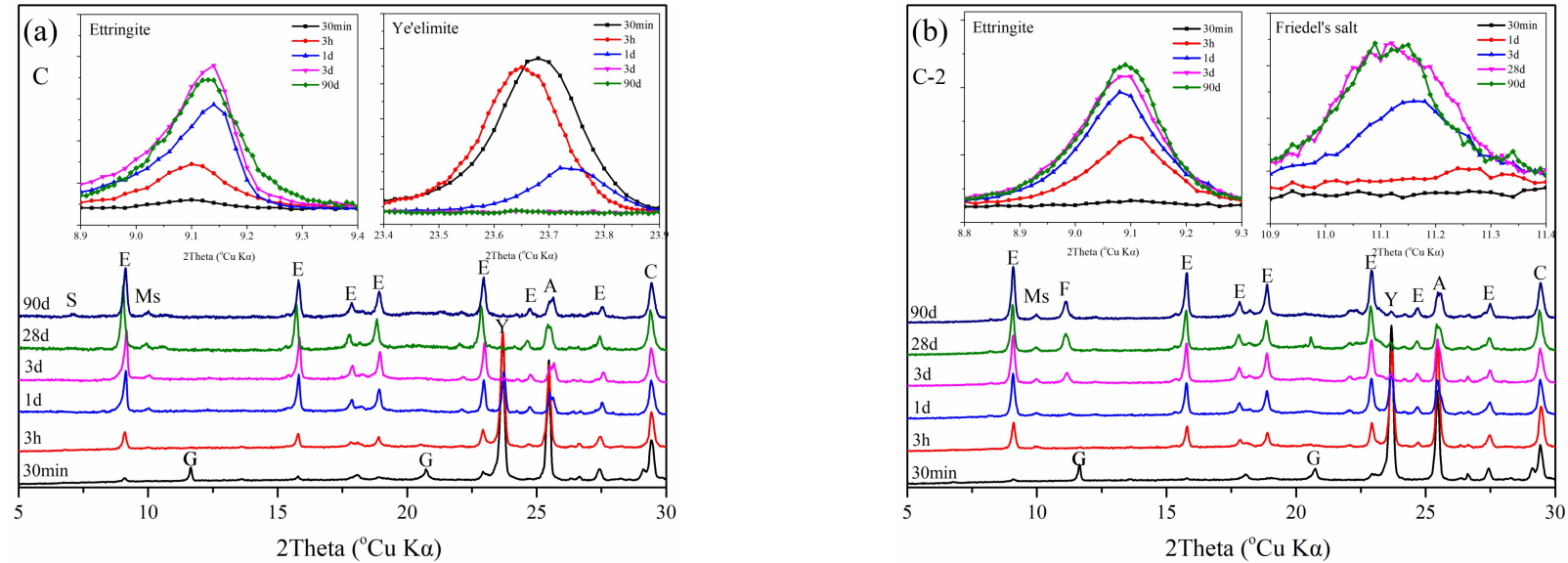

Figure 6. XRD patterns of the CSA cement paste of sample $C(\mathbf{a})$ and sample C-2 (b) at different curing ages (E-Ettringite, G-Gypsum, Ms-Monosulphoaluminate, Y-Ye'elimite, F-Friedel's, C-Calcite, A-Anhydrite, S-Strätlingite).

The XRD patterns of CSA cement mixed with $\mathrm{CaCO}_{3}$, or gypsum are shown in Figure 7 . It can be seen that the $\mathrm{Hc}$ is observed and $\mathrm{Mc}$ is not shown when CSA is mixed with $5 \%$ $\mathrm{CaCaO}_{3}$ (Equation (7)) [43]. Meanwhile, Hc phase is still not observed in C. Thus, the diffraction peak intensity of Friedel's salt in CC5-2 and CS5-2 is lower than that of pure CSA cement (sample C-2). This is owing to the fact that $\mathrm{CaCO}_{3}$ and gypsum contribute to the formation of ettringite when AFm phase is reduced. Herein, the formation of Friedel's salt is inhibited:

$$
\begin{gathered}
3 \mathrm{CH}+3 \mathrm{C} \overline{\mathrm{S}}+\mathrm{AH}_{3}+26 \mathrm{H}=\mathrm{C}_{6} \mathrm{~A}_{3} \mathrm{H}_{32}(\mathrm{AFt}) \\
\mathrm{C}_{4} \mathrm{AS} \mathrm{H}_{12}+2 \mathrm{Cl}^{-}=\mathrm{C}_{4} \mathrm{ACl}_{2} \mathrm{H}_{11}\left(\text { Friedel }^{\prime} \text { s salt }\right)+\mathrm{SO}_{4} 2^{-}+2 \mathrm{H} \\
2 \mathrm{C}_{2} \mathrm{~S}+4 \mathrm{AH}_{3}+5 \mathrm{H}=\mathrm{C}_{2} \mathrm{ASH}_{8} \\
6 \mathrm{C}_{4} \mathrm{~A}_{3} \overline{\mathrm{S}}+2 \mathrm{C} \overline{\mathrm{C}}+135 \mathrm{H}=2 \mathrm{C}_{4} \mathrm{AC}_{0.5} \mathrm{H}_{11}(\mathrm{Hc})+2 \mathrm{AFt}+14 \mathrm{AH}_{3}+5 \mathrm{CH}
\end{gathered}
$$




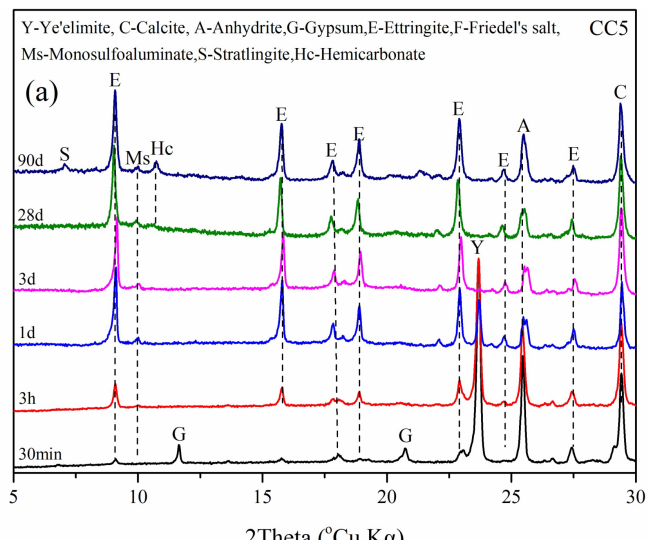

2Theta $\left({ }^{\circ} \mathrm{Cu} \mathrm{K} \alpha\right)$
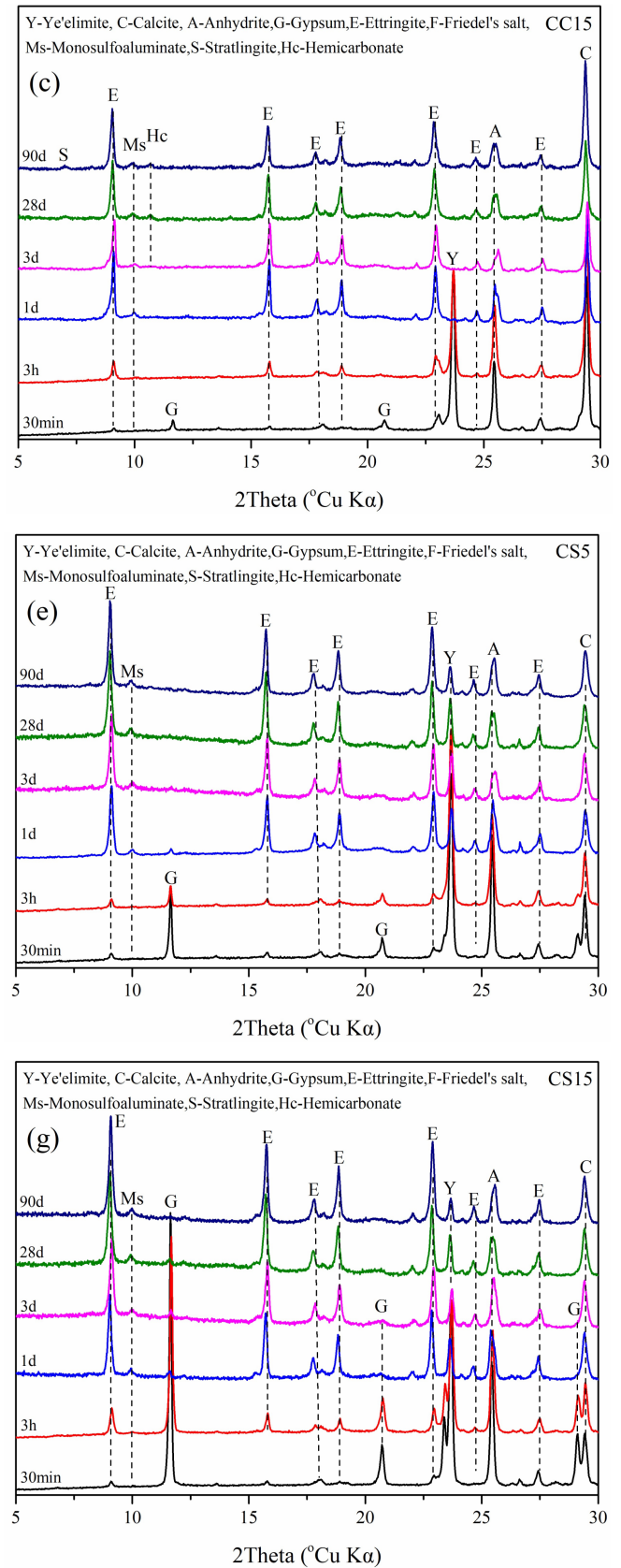

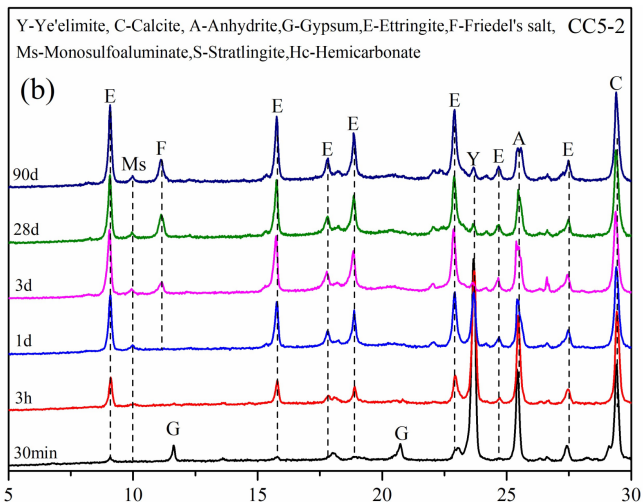

2Theta $\left({ }^{\circ} \mathrm{Cu} \mathrm{K} \alpha\right)$
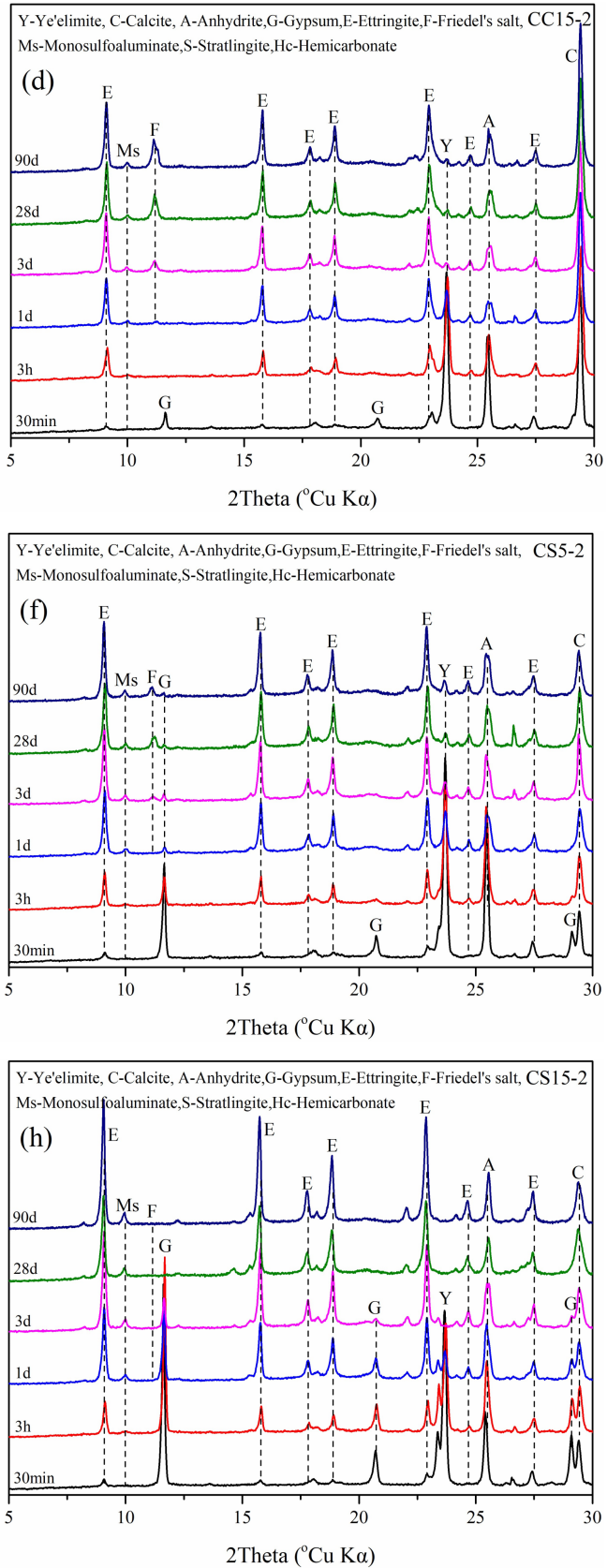

Figure 7. XRD patterns of paste samples of CC5 (a), CC5-2 (b), CC15 (c), CC15-2 (d), CS5 (e), CS5-2 (f), CS15 (g) and CS15-2 (h). 
(Notation with: $\mathrm{C}=\mathrm{CaO}, \mathrm{A}=\mathrm{Al}_{2} \mathrm{O}_{3}, \overline{\mathrm{S}}=\mathrm{SO}_{3}, \overline{\mathrm{C}}=\mathrm{CO}_{2}, \mathrm{~S}=\mathrm{SiO}_{2}, \mathrm{H}=\mathrm{H}_{2} \mathrm{O}$ ).

Quantitative calculation of the degree of hydration and content of Friedel's salt under $\mathrm{NaCl}$ solutions is shown in Figure 8. The cement paste combines with chloride ions to generate Friedel's salt due to the presence of Afm phase in the cement at the initial stage of erosion [44]. With the consumption of Afm phase, the content of Friedel's salt reaches a stable level gradually. In comparison, the content of Friedel's salt in C-2 is significantly higher than that of CC5-2 and CC15-2, indicating that the addition of $\mathrm{CaCO}_{3}$ reduces the formation of Friedel's salt. The reason is that $\mathrm{CaCO}_{3}$ will reduce the formation of Afm phases. Therein, the contents of Afm phases are reduced and the formation of Friedel's salt deteriorates. The presence of Gypsum promotes the formation of ettringite and reduces the formation of Afm, which greatly limits the formation of Friedel's salt. CS15-2 makes this particularly obvious:
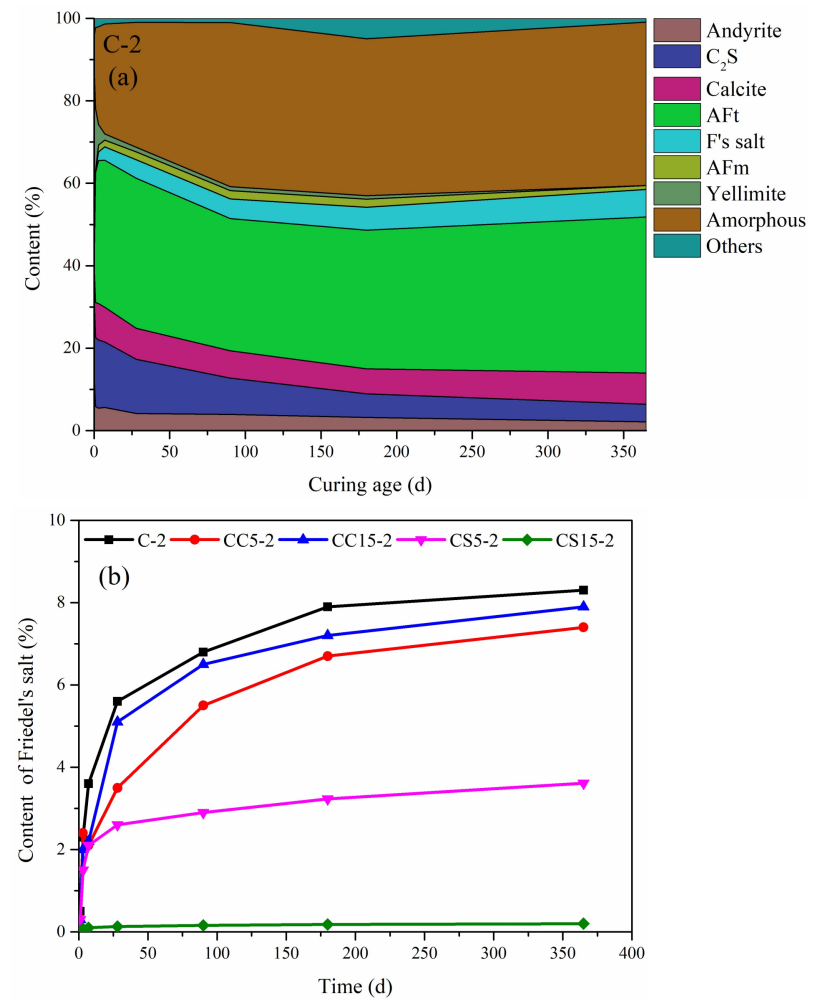

Figure 8. Quantitative calculation of hydration degree (a) and Friedel's salt content (b) under $\mathrm{NaCl}$ solutions.

\subsection{Pore Size Distribution}

Figure 9 exhibits the pore size distribution and accumulated porosity of pure CSA cement paste and CSA cement pastes with $\mathrm{CaCO}_{3}$ and gypsum under $\mathrm{NaCl}$ solutions over 180 days. When hydrated for 3 days, the presence of $\mathrm{CaCO}_{3}$ and gypsum will promote the formation of larger width pores [45]. As discussed above, $\mathrm{CaCO}_{3}$ and gypsum promote the formation of ettringite, then larger sized ettringite crystals will easily form in the early curing phase, which will lead the formation of larger pore spaces. The role of gypsum is particularly obvious [46]. This is the main reason why the porosity of the CSA paste mixed with gypsum is lower than that of CSA samples mixed with $\mathrm{CaCO}_{3}$. The presence of $\mathrm{CaCO}_{3}$ and gypsum optimizes the pore structure over longer-term curing times. Appropriate amounts of $\mathrm{CaCO}_{3}$ and gypsum have a positive effect on the densification of cement pore structure. 

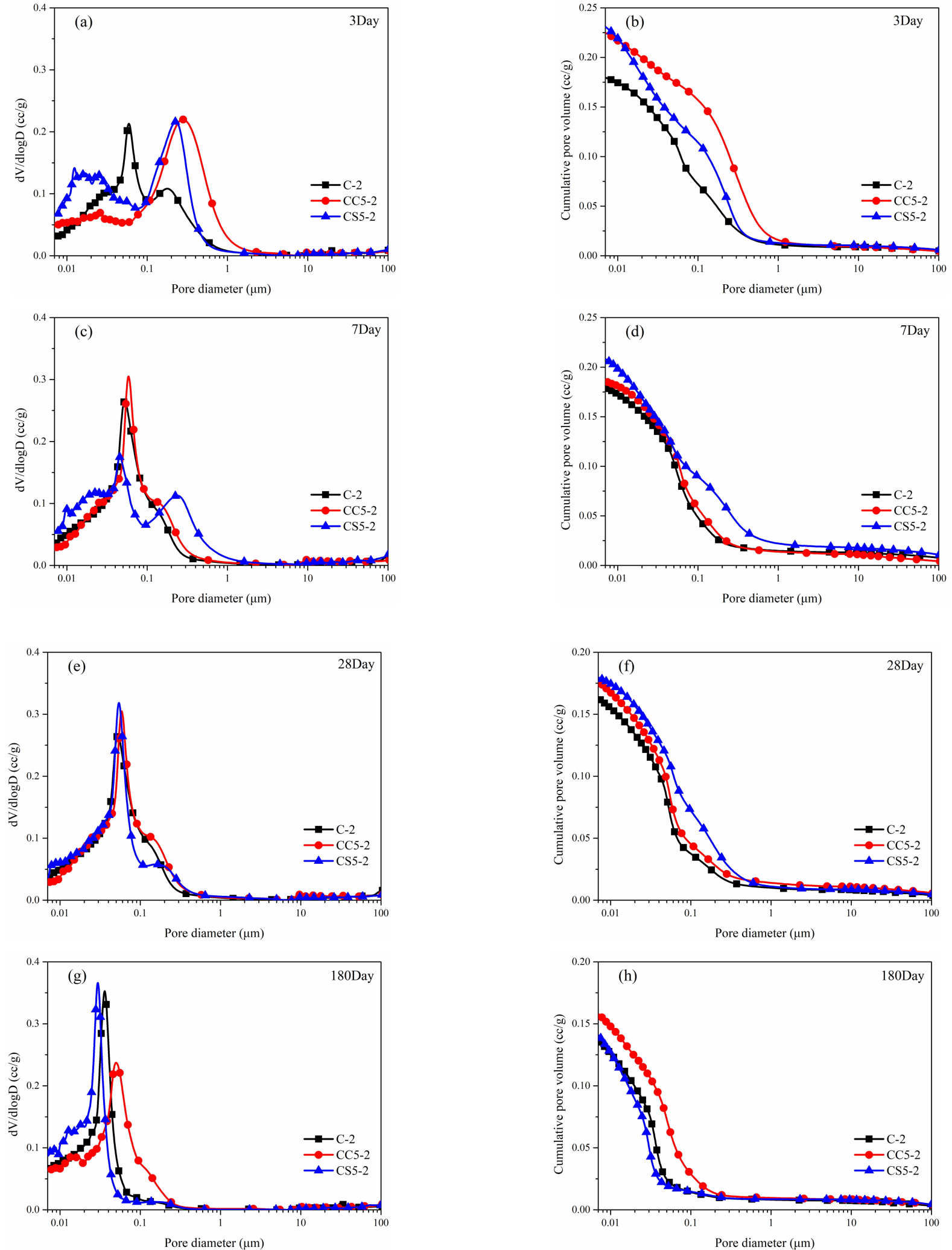

Figure 9. Distribution curve $(\mathbf{a}, \mathbf{c}, \mathbf{e}, \mathbf{g})$ and cumulative intrusion curve $(\mathbf{b}, \mathbf{d}, \mathbf{f}, \mathbf{h})$ of the hydrated samples at different ages under $3.5 \% \mathrm{NaCl}$ solutions.

Figure 10 shows the total porosity of CSA pastes with $\mathrm{CaCO}_{3}$ and gypsum within 180 days of curing in an $\mathrm{NaCl}$ solution. Clearly, the total porosity of hydrated paste 
decreases as curing time increases. The total porosity of CSA samples with $\mathrm{CaCO}_{3}$ and gypsum were higher than that of pure CSA cement:

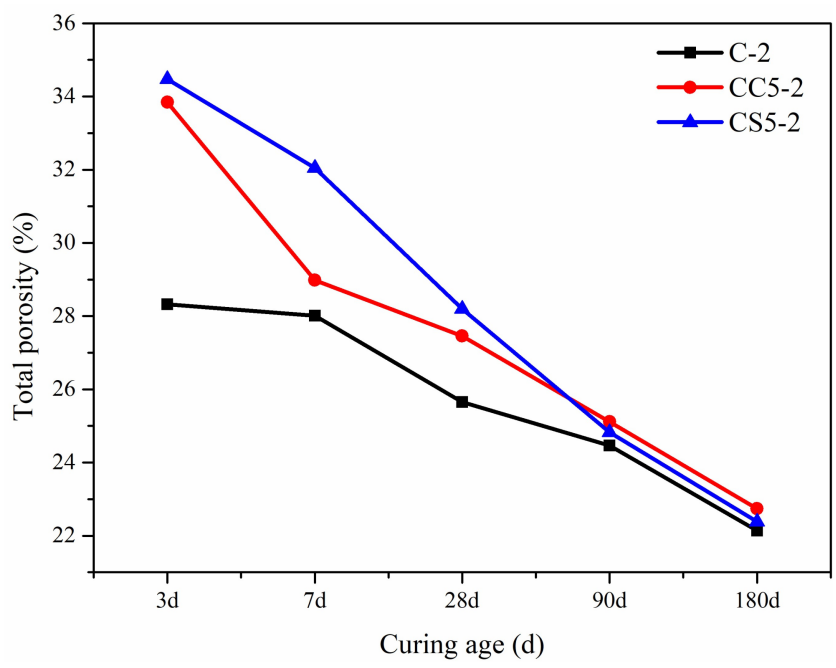

Figure 10. Total porosity development of the hydrated sample up to 180 days.

\subsection{Linear Shrinkage}

Linear shrinkage rate curves of the cement pastes within 180 days are shown in Figure 11. Under standard curing conditions, the expansion of CSA cement is owed to the formation of ettringite during the early hydration and hardening process, while the shrinkage is caused by the free water consumption and the reactions of cement in later phases [47]. It was clear that the shrinkage rate of all samples increased and gradually stabilized as curing times extended.

The shrinkage rate of the CSA cement pastes containing $\mathrm{CaCO}_{3}$ decreased compared to that of pure CSA cement. The shrinkage rate of CC15 is minimal, which was caused by the $\mathrm{CaCO}_{3}$ acting as a filler. $\mathrm{CaCO}_{3}$ can also stabilize ettringite and dilute cement [48]. On the contrary, samples containing gypsum had a higher shrinkage rates. This may be related to the later transformation of ettringite [49].

Under $\mathrm{NaCl}$ solutions, the drying shrinkage of all samples obviously decreased. The chloride ions, who were invaded in the cement pastes, were chemically combined with AFm phase, which helped the formation and stabilization of ettringite. Accordingly, the shrinkage was reduced. In the early stage of hydration, the shrinkage rate changes greatly due to larger pore sizes. As pore sizes tend to become finer as curing time increases, the shrinkage rate tends to stabilize.

\subsection{Compressive Strength of Mortar Samples}

\subsubsection{Compressive Strength of Fresh Water Mixing}

Compressive strengths of CSA cement mortars containing $\mathrm{CaCO}_{3}$ or gypsum are shown in Figure 12. The compressive strength of all blended mortars increased as the curing time extended. CSA mortars blending with $\mathrm{CaCO}_{3}$ had lower compressive strength than that of pure CSA mortars, and the trend seemed to become more obvious by increasing the content of $\mathrm{CaCO}_{3} \cdot \mathrm{CaCO}_{3}$ is mainly used as a filler, it basically does not participate in chemical reaction $[40,50]$. For $\mathrm{CC} 5$, the loss of strength was minimal when $\mathrm{CaCO}_{3}$ is used. However, CS5 and CS10 showed higher compressive strength than plain CSA cement mortar. After 3 days, CS10 produced a higher compressive strength than CS5, and a similar strength was reached after 90 days. Gypsum could react with $\mathrm{C}_{4} \mathrm{~A}_{3} \bar{S}$ to form ettringite and improve early compressive strength [51]. 


\subsubsection{Compressive Strength of $\mathrm{NaCl}$ Solutions Curing}

Under $\mathrm{NaCl}$ solutions, the compressive strength of all samples increased steadily. $\mathrm{CaCO}_{3}$ and gypsum played a similar role in the development of compressive strength compared with freshwater curing. In the presence of chloride ions, the compressive strength increased due to the formation of Friedel's salt. CS5-2 and CS10-2 reached similar compressive strengths after 90 days. It should be noted that the large amount of ettringite generated inside the mortar sample containing gypsum improved the compressive strength on the one hand, but made the cement mortar more brittle on the other. Although the compressive strength of CC5-2 is lower than that of C-2, the 28-day compressive strength can fully meet the mechanical requirements of $42.5 \mathrm{Mpa}$ while decreasing the shrinkage rate.
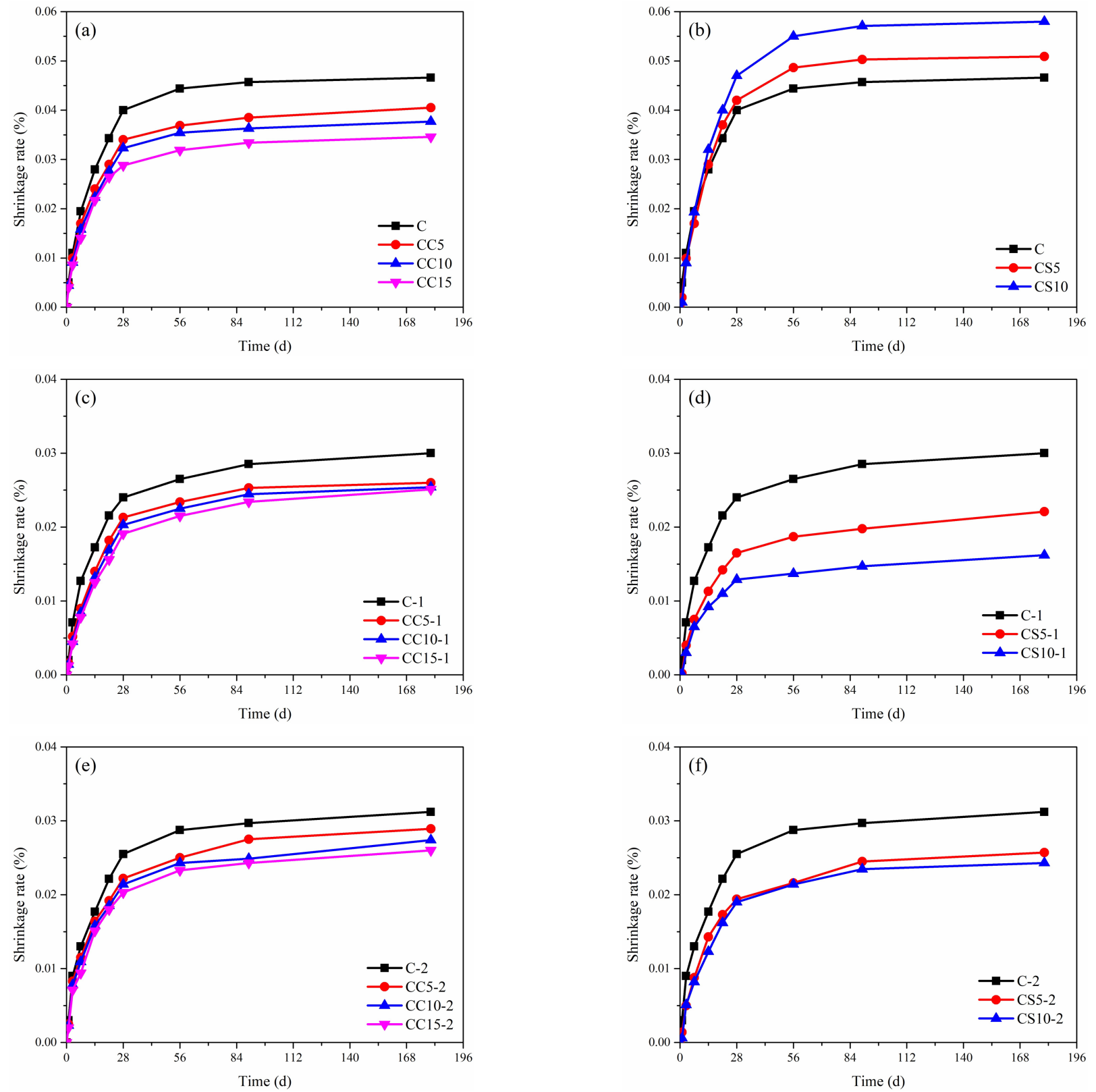

Figure 11. Linear shrinkage rate of paste specimens mixed $\mathrm{CaCO}_{3}(\mathbf{a}, \mathbf{c}, \mathbf{e})$ or gypsum $(\mathbf{b}, \mathbf{d}, \mathbf{f})$ at different ages. 

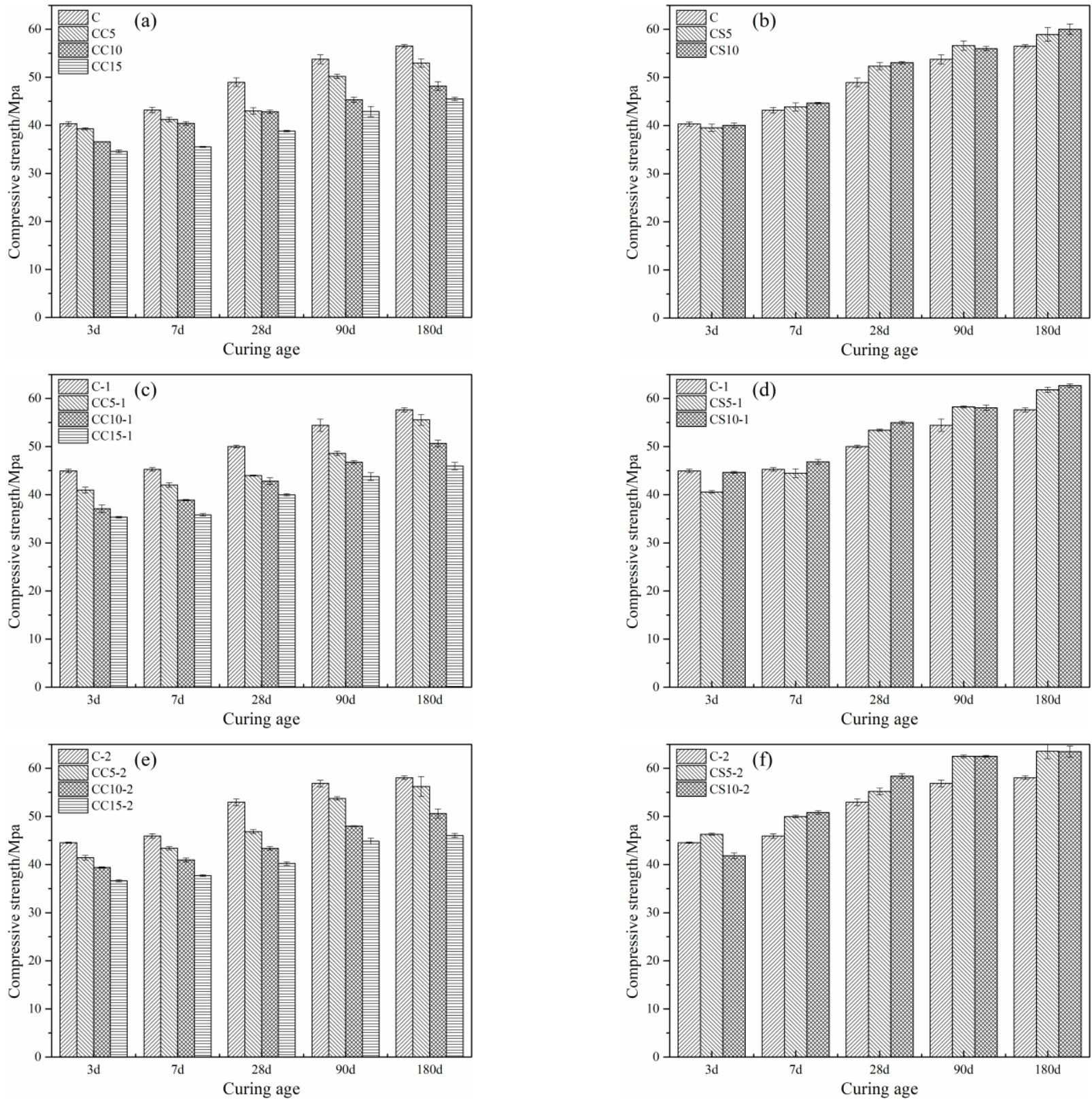

Figure 12. Compressive strength of CSA cement mixed $\mathrm{CaCO}_{3}(\mathbf{a}, \mathbf{c}, \mathbf{e})$ or gypsum $(\mathbf{b}, \mathbf{d}, \mathbf{f})$ at different ages.

\section{Conclusions}

This study investigated the influence of $\mathrm{CaCO}_{3}$ and gypsum on the hydration and compressive strength of CSA cement under fresh water and $\mathrm{NaCl}$ solutions at curing times of up to 180 days. The hydration heat evolution, hydration products and compressive strength were investigated and discussed. Results obtained are as follows:

(1) $\mathrm{CaCO}_{3}$ and gypsum both accelerate the early hydration of CSA cement and reduce the 3-day accumulate hydration heat.

(2) Under $\mathrm{NaCl}$ solutions, $\mathrm{CaCO}_{3}$ can react with $\mathrm{C}_{4} \mathrm{~A}_{3} \overline{\mathrm{S}}$ to form $\mathrm{Hc}$, which can combine with $\mathrm{Cl}^{-}$to form Friedel's salt, while gypsum readily reacts with $\mathrm{C}_{4} \mathrm{~A}_{3} \bar{S}$ to form ettringite. Both $\mathrm{CaCO}_{3}$ and gypsum can reduce the content of bound chloride ions in CSA cement paste.

(3) $\mathrm{CaCO}_{3}$ and gypsum will obviously increase the pore size of the cement paste in the early curing stages and the pore size will become finer as the curing time extends. The 
total porosity of CSA with $\mathrm{CaCO}_{3}$ and gypsum is higher than that of CSA cement up to 180 days.

(4) The diluting effect of $\mathrm{CaCO}_{3}$ reduces the shrinkage rate of cement paste, while the shrinkage rate found by adding gypsum is higher due to the transformation of ettringite. Under $\mathrm{NaCl}$ solutions, the shrinkage rates of CSA obviously decreases.

(5) The compressive strength of CSA mortars containing $\mathrm{CaCO}_{3}$ decreases, while gypsum can increase the compressive strength of mortar samples. Under $\mathrm{NaCl}$ solutions, the compressive strength develops better.

Author Contributions: Conceptualization, J.W., S.S. and Y.Z.; methodology, J.W.; software, J.W. and T.X.; validation, S.S. and Y.Z.; formal analysis, Y.Z. and H.Q.; investigation, Y.Z.; resources, Y.Z.; data curation, Y.Z. and Y.M.; writing—original draft preparation, J.W.; writing-review and editing, J.W., Y.Z., and H.Q.; visualization, J.W.; supervision, Y.Z. and H.Q.; project administration, Y.Z.; funding acquisition, Y.Z. and H.Q. All authors have read and agreed to the published version of the manuscript.

Funding: This research was funded by the National Key R\&D Program of China (Grant No. 2017YFB0309902), the Priority Academic Program Development of Jiangsu Higher Education Institutions (PAPD), and the Changjiang Scholars and Innovative Research Team in University (No. IRT_15R35).

Acknowledgments: The authors would like to acknowledge financial support from the National Key R\&D Program of China (Grant No. 2017YFB0309902), the Priority Academic Program Development of Jiangsu Higher Education Institutions (PAPD), and the Changjiang Scholars and Innovative Research Team in University (No. IRT_15R35).

Conflicts of Interest: The authors declare no conflict of interest.

\section{References}

1. Qiao, C.; Suraneni, P.; Weiss, J. Damage in cement pastes exposed to NaCl solutions. Constr. Build. Mater. 2018, 171, 120-127. [CrossRef]

2. De Weerdt, K.; Justnes, H.; Geiker, M.R. Changes in the phase assemblage of concrete exposed to sea water. Cem. Concr. Compos. 2014, 47, 53-63. [CrossRef]

3. Gartner, E. Industrially interesting approaches to "low- $\mathrm{CO}_{2}$ " cements. Cem. Concr. Compos. 2004, 34, 1489-1498. [CrossRef]

4. Wang, Z.; Zhang, B.; Yin, J. Determinants of the increased $\mathrm{CO}_{2}$ emission and adaption strategy in Chinese energy-intensive industry. Nat. Hazards 2011, 62, 17-30. [CrossRef]

5. Quillin, K. Performance of belite-sulfoaluminate cements. Cem. Concr. Res. 2001, 31, 1341-1349. [CrossRef]

6. Ioannou, S.; Paine, K.; Reig, L.; Quillin, K. Performance characteristics of concrete based on a ternary calcium sulfoaluminateanhydrite-fly ash cement. Cem. Concr. Compos. 2015, 55, 196-204. [CrossRef]

7. Popescu, C.D.; Muntean, M.; Sharp, J.H. Industrial trial production of low energy belite cement. Cem. Concr. Compos. 2003, 25, 689-693. [CrossRef]

8. Wang, X.; Wang, J. Development and production of sulphoaluminate series cement. China Enamel 1998, 4, 3-5.

9. Wang, J.; Zhang, Z.; Wan, S. The development status and prospect of sulphoaluminate cement. New Century Cem. Guide 2011, 17, $51-53$.

10. Huang, W.; Wen, Z.; Wang, M. Research Progress of Cement for Marine Engineering. Portland Bull. 2017, 36, 3708-3713.

11. Wang, C.; Gao, H. Performance test of high-durability concrete for rapid construction. Water Transp. Eng. 2019, 6, 34-38.

12. Zhang, Y.; Zhuang, H.; Shi, J.; Huang, J.; Zhang, J. Time-dependent characteristic and similarity of chloride diffusivity in concrete. Mag. Concr. Res. 2018, 70, 129-137. [CrossRef]

13. Wang, W.; Lu, C. Time-varying law of rebar corrosion rate in fly ash concrete. J. Hazard. Mater. 2018, 360, 520-528. [CrossRef] [PubMed]

14. Martin-Perez, B.; Zibarab, H.; Hootonb, R.D.; Thomas, M.D.A. A study of the effect of chloride binding on service life predictions. Cem. Concr. Res. 2000, 30, 1215-1223. [CrossRef]

15. Chang, H.; Feng, P.; Lyu, K.; Liu, J. A novel method for assessing C-S-H chloride adsorption in cement pastes. Constr. Build. Mater. 2019, 225, 324-331. [CrossRef]

16. Falzone, G.; Balonis, M.; Sant, G. X-AFm stabilization as a mechanism of bypassing conversion phenomena in calcium aluminate cements. Cem. Concr. Res. 2015, 72, 54-68. [CrossRef]

17. Pelletier-Chaignat, L.; Winnefeld, F.; Lothenbach, B.; Müller, C.J. Beneficial use of limestone filler with calcium sulphoaluminate cement. Constr. Build. Mater. 2012, 26, 619-627. [CrossRef]

18. Kevin, D.; Ingram, K.E.D. A Review of Limestone Additions to Portland Cement and Concrete. Cem. Concr. Res. 1991, 13, 165-170. 
19. Dhandapani, Y.; Santhanam, M.; Kaladharan, G.; Ramanathan, S. Towards ternary binders involving limestone additions-A review. Cem. Concr. Res. 2021, 143, 106396. [CrossRef]

20. Xu, J.; Chen, J.; Lu, D.; Xu, Z.; Hooton, R.D. Effect of dolomite powder on the hydration and properties of calcium sulfoaluminate cements with different gypsum contents. Constr. Build. Mater. 2019, 225, 302-310. [CrossRef]

21. Shi, H.; Yu, Z.; Ma, J.; Ni, C.; Shen, X. Properties of Portland cement paste blended with coral sand powder. Constr. Build. Mater. 2019, 203, 662-669. [CrossRef]

22. Shi, H.; Wu, Q.; Yu, Z.; Ma, J.; Shen, X. Properties of eco-friendly coral sand powder-Calcium sulfoaluminate cement binary system. Constr. Build. Mater. 2020, 263, 120181. [CrossRef]

23. Ma, J.; Yu, Z.; Ni, C.; Shi, H.; Shen, X. Effects of limestone powder on the hydration and microstructure development of calcium sulphoaluminate cement under long-term curing. Constr. Build. Mater. 2019, 199, 688-695. [CrossRef]

24. Zhao, J.; Cai, G.; Gao, D. Analysis of anti-chloride ion corrosion mechanism of sulphoaluminate cement concrete. J. Build. Mater. 2011, 14, 357-361.

25. Li, P.; Ma, Z.; Zhang, Z.; Li, X.; Lu, X.; Hou, P.; Du, P. Effect of Gypsum on Hydration and Hardening Properties of Alite Modified Calcium Sulfoaluminate Cement. Materials 2019, 12, 3131. [CrossRef] [PubMed]

26. Pelletier-Chaignat, L.; Winnefeld, F.; Lothenbach, B.; Saout, G.L.; Müller, C.J.; Famy, C. Influence of the calcium sulphate source on the hydration mechanism of Portland cement-calcium sulphoaluminate clinker-calcium sulphate binders. Cem. Concr. Compos. 2011, 33, 551-561. [CrossRef]

27. Allevi, S.; Marchi, M.; Scotti, F.; Bertini, S.; Cosentino, C. Hydration of calcium sulphoaluminate clinker with additions of different calcium sulphate sources. Mater. Struct. 2015, 49, 453-466. [CrossRef]

28. Huang, Y.; Li, X.; Lu, Y.; Wang, H.; Wang, Q.; Sun, H.; Li, D. Effect of mix component on the mechanical properties of coral concrete under axial compression. Constr. Build. Mater. 2019, 223, 736-754. [CrossRef]

29. Zhang, B.; Zhu, H.; Wang, Q.; Shah, K.W.; Wang, W. Design and properties of seawater coral aggregate alkali-activated concrete. J. Sustain. Cem.-Based Mater. 2021, 1-15. [CrossRef]

30. Montanari, L.; Suraneni, P.; Tsui-Chang, M.; Khatibmasjedi, M.; Ebead, U.; Weiss, J.; Nanni, A. Hydration, Pore Solution, and Porosity of Cementitious Pastes Made with Seawater. J. Mater. Civil Eng. 2019, 31, 04019154. [CrossRef]

31. Goñi, S.; Frias, M.; Vigil de la Villa, R.; García, R. Sodium chloride effect on durability of ternary blended cement. Microstructural characterization and strength. Compos. Part B Eng. 2013, 54, 163-168. [CrossRef]

32. Frias, M.; Goñi, S.; García, R.; Vigil de La Villa, R. Seawater effect on durability of ternary cements. Synergy of chloride and sulphate ions. Compos. Part B Eng. 2013, 46, 173-178. [CrossRef]

33. Cao, Y.; Guo, L.; Xue, X. The influence of $\mathrm{NaCl}$ and $\mathrm{Na}_{2} \mathrm{SO}_{4}$ on the mechanism of cement hydration. J. Southeast Univ. (Nat. Sci. Ed.) 2019, 49, 712-719.

34. Quennoz, A.; Scrivener, K.L. Hydration of C3A-gypsum systems. Cem. Concr. Res. 2012, 42, 1032-1041. [CrossRef]

35. Pang, X.; Boul, P.; Cuello Jimenez, W. Isothermal calorimetry study of the effect of chloride accelerators on the hydration kinetics of oil well cement. Constr. Build. Mater. 2015, 77, 260-269. [CrossRef]

36. Sim, S.; Lee, H.; Jeon, D.; Song, H.; Yum, W.; Kim, D.; Suh, J.-I.; Oh, J. Gypsum-Dependent Effect of NaCl on Strength Enhancement of CaO-Activated Slag Binders. Appl. Sci. 2018, 8, 2515. [CrossRef]

37. Tang, S.W.; Zhu, H.G.; Li, Z.J.; Chen, E.; Shao, H.Y. Hydration stage identification and phase transformation of calcium sulfoaluminate cement at early age. Constr. Build. Mater. 2015, 75, 11-18. [CrossRef]

38. Shen, Y.; Chen, X.; Zhang, W.; Li, X. Effect of ternesite on the hydration and properties of calcium sulfoaluminate cement. J. Therm. Anal. Calorim. 2018, 136, 687-695. [CrossRef]

39. Li, C.; Wu, M.; Yao, W. Eco-efficient Cementitious System Consisting of Belite-Ye'elimite-Ferrite Cement, Limestone Filler, and Silica Fume. ACS Sustain. Chem. Eng. 2019, 7, 7941-7950. [CrossRef]

40. Jeong, Y.; Hargis, C.W.; Chun, S.; Moon, J. Effect of Calcium Carbonate Fineness on Calcium Sulfoaluminate-Belite Cement Materials 2017, 10, 900. [CrossRef]

41. Zhen, H.; Yang, H.; Liu, M. Hydration Mechanism of Sulphoaluminate Cement. J. Wuhan Univ. Technol.-Mater. Sci. Ed. 2014, 29, 70-74.

42. Guo, M.; Xiao, J.; Wang, J. Impact of the coupled substitution of $\mathrm{CaCO}_{3}$ and $\mathrm{CaSO}_{4} \cdot 2 \mathrm{H}_{2} \mathrm{O}$ on chloride binding behavior in hydrated $\mathrm{C}_{3} \mathrm{~A}$ pastes. Constr. Build. Mater. 2019, 217, 638-650. [CrossRef]

43. Baquerizo, L.G.; Matschei, T.; Scrivener, K.L.; Saeidpour, M.; Wadsö, L. Hydration states of AFm cement phases. Cem. Concr. Res. 2015, 73, 143-157. [CrossRef]

44. Zhu, Q.; Jiang, L.; Chen, Y.; Xu, J.; Mo, L. Effect of chloride salt type on chloride binding behavior of concrete. Constr. Build. Mater. 2012, 37, 512-517. [CrossRef]

45. Birnin-Yauri, U.A.; Glasser, F.P. Friedel's salt, $\mathrm{Ca}_{2} \mathrm{Al}(\mathrm{OH})_{6}(\mathrm{Cl}, \mathrm{OH})_{2} 2 \mathrm{H}_{2} \mathrm{O}$ its solid solutions and their role in chloride binding. Cem. Concr. Res. 1998, 28, 1713-1723. [CrossRef]

46. Elgalhud, A.A.; Dhir, R.K.; Ghataora, G. Limestone addition effects on concrete porosity. Cem. Concr. Compos. 2016, 72, 222-234 [CrossRef]

47. Shi, X. Research on CSA High Performance Cement Concrete Shrinkage and Creep. Qinghai Transp. Technol. 2020, $32,83-87$.

48. Shoude, W.; Cheng, C.; Lingchao, L.; Xin, C. Effects of slag and limestone powder on the hydration and hardening process of alite-barium calcium sulphoaluminate cement. Constr. Build. Mater. 2012, 35, 227-231. [CrossRef] 
49. Berger, S.; Cau Dit Coumes, C.; Le Bescop, P.; Damidot, D. Stabilization of $\mathrm{ZnCl}_{2}$-containing wastes using calcium sulfoaluminate cement: Cement hydration, strength development and volume stability. J. Hazard. Mater. 2011, 194, 256-267. [CrossRef]

50. Li, X.; Ma, Y.; Shen, X.; Zhong, Y.; Li, Y. Study of Hydration and Microstructure of Mortar Containing Coral Sand Powder Blended with SCMs. Materials 2020, 13, 4248. [CrossRef]

51. Subramanian, S.; Khan, Q.; Ku, T. Strength development and prediction of calcium sulfoaluminate treated sand with optimized gypsum for replacing OPC in ground improvement. Constr. Build. Mater. 2019, 202, 308-318. [CrossRef] 